Historia y comunicación social

ISSN: 1137-0734

http://dx.doi.org/10.5209/hics.75710

\title{
Some room for us: Women in academia as seen through the lives of Canada's Eliza Ritchie (1856-1933) and Spain’s María Goyri (1873-1954)
}

Sara Herrero'; Allyson Jule²

Recibido el: 29 de enero de 2020 / Aceptado: 13 de septiembre de 2020

Abstract. This paper explores the experience of women in academia by looking both back and at the present. We consider two women who searched for and found academic accomplishment. Together, they serve as representatives of a new way of living for women in the late-19 $9^{\text {th }}$ and early-20 $0^{\text {th }}$ centuries. Eliza Ritchie (1856-1933) from Canada and María Goyri (1873-1954) from Spain are exemplars of the emerging contributions of women in the academy as part of the changing role for women in Western culture and the need for women to support each other in shared feminist causes. These women shared the same time period, the same intellectual values, the same commitment to scholarship, and the same incredible determination to help develop a modern society that could embrace the full incorporation of women. This paper considers their accomplishments in light of academia today in both Canada and Spain in regards to the advancement of women. It also examines some lingering inequalities in terms of tenure and promotion, salary, research capacity, administrative and leadership positions. Such an international collaboration contributes to the shared sense of sisterhood for women in academia today.

Keywords: Academic women; University; S.XIX; S.XXIv Canada; Spain; West; OECD.

[es] Espacio para nosotras: La mujer académica de hoy vista a través de las trayectorias de la canadiense Eliza Ritchie (1856-1933) y la española María Goyri (1873-1954)

Resumen. Este artículo explora la situación de las mujeres académicas en la Universidad de hoy, tomando como referencia el momento de su incorporación. Para ello se estudia la trayectoria de dos mujeres, pioneras estudiantes, y académicas después, que ocupan espacios restringidos para ellas hasta entonces. La canadiense Eliza Ritchie (1856-1933) y la española María Goyri (1873-1954) son ejemplo de la emergente contribución de las mujeres en la Academia y parte fundamental del cambio de roll que jugará la mujer en los sistemas académicos de Occidente. Contemporáneas, y con una sólida trayectoria académica, compartieron su compromiso con el papel clave del conocimiento en el desarrollo de las sociedades. También con la defensa respecto al papel imprescindible, en igualdad de condiciones que el hombre, que debía jugar la mujer en la sociedad. Desde su incorporación al mundo académico los logros conseguidos han sido muy importantes. Sin embargo, el artículo analiza cómo, ser mujer o hombre, sigue determinando la carrera académica en Canadá y en España en términos del puesto ocupado, de las posibilidades de promoción, del salario recibido, y de la capacidad investigadora. Un problema que excede fronteras y al que esta colaboración internacional pretende contribuir con un sentido de hermandad. Palabras clave: Mujeres académicas; Universidad; S.XIX; S.XXI; Canadá; España; Occidente; OCDE.

Contents: 1. Introduction. 2. The contributions of Eliza Ritchie (1856-1933). 3. The contributions of María Goyri (1873-1954). 4. Ritchie and Goyri comparative analysis. 5. Women in the academia today: Canada and Spain. 6. Some Conclusions. 7. Bibliography.

Cómo citar: Herrero, S.; Jule, A. (2020) Some room for us: Women in academia as seen through the lives of Canada's Eliza Ritchie (1856-1933) and Spain's María Goyri (1873-1954), Historia y comunicación social 26(1), 215-224.

Universidad Europea de Madrid

E-mail: saraherrero.edu@gmail.com

ORCID: https://orcid.org/0000-0001-5174-6898

2 Trinity Western University, Vancouver, BC, Canadá

E-mail: allyson.Jule@twu.ca

Hist. comun. soc. 26(1) 2021: 215-224 
So long as you write what you wish to write, that is all that matters; and whether it matters for ages or only for hours, nobody can say. Virginia Woolf, A room of one's own (1929)

\section{Introduction}

Today's academic women face many of the same burdens as men: the pressures of tenure and promotion, the demands of teaching and writing, the requirements to serve on university committees and academic associations, as well as the need to manage and tend to one's personal life. And yet, gender determines one's academic career. The gender gap cuts across national and international boundaries; evidence of it has been found over many decades in all Western academic systems (Baker, 2012, Gómez, 2016). The gender gap also defines academic trajectories in terms of tenure, promotion, salary, research capacity and administrative leadership positions (Lee, 2014: 331-332). The burdens of academic life are too often heavier for women.

The comparative studies on the role of women in different educational systems considered by countries or regions are fundamental to the historiography of women (Montero, 2009: 45). Much feminist literature shows particular experiences of women within academia in Western countries through a reflexive life story approach (Baker, 2012; Rogers, 2017). We also use this approach in this comparative analysis that sheds light on the shared feminist history of academic women. Our research is presented here with a view to inspire female academics to persevere as they confront the challenges of academia for women today.

We are two academic women, one in Canada and one in Spain. We publish and research in differing disciplines (Education and Economics, respectively); however, we come together in this article to explore some realities faced by academic women from an international and historical perspective. We aim to achieve this by considering two women who lived a century ago who searched for and found academic accomplishment. Together, they serve as representatives of a new way of living for women in the late- $19^{\text {th }}$ and early- $20^{\text {th }}$ centuries. Eliza Ritchie from Canada and María Goyri from Spain are exemplars of the emerging contributions of women in the academy as part of the changing role for women in Western culture and the need for women to support each other in shared feminist causes. Our academic disciplines, and those of our exemplars, are not of prime significance here. What is critical is a sense of connection we feel as academic women to these exemplars and to women scholars in other academic systems. The lives of Eliza Ritchie and her contemporary María Goyri resonate in ways that encourage us to persevere with the intellectual life and to see the academic world as a house of sorts - one that is big enough to include women's contributions. By researching the lives of these two academic women, we have come to appreciate our own lives as female scholars, even while exploring and experiencing the injustices that remain.

Ritchie and Goyri were not the only "firsts" in academia. There were other trailblazers from England, France, Italy, etc. who rejected Victorian attitudes and patriarchal/colonial perspectives and called for more modern ideas of diversity and inclusion. Yet, women such as the "London nine" in the UK, Julie-Victoire Daubié in France and Catherine Brewer in the US were rarities among their nation's population, when the norm for both women and men was not receiving even a high school diploma (Miller, 1985: 63). We narrow our focus to Ritchie and Goyri as exemplary women from the countries from which we as academics hail. We present these two women's social practices and activism, and we consider their own professional trajectories. They belong to the small group of women who created a public identity for females in academia through their writing and organizational talents (Duby, 1994: 497). As historian Mary Beard wrote (cited in Evans, 1989: 5) we want to know how the experiences of women have actively shaped the broader history that we claim as our own. Our focus is on Ritchie and Goyri, and yet we draw on English writer Virginia Woolf's seminal text, $A$ room of one's own (1929), to ask, "Is there some room for us?"

Exploring the lives of Ritchie and Goyri, together, provides us with some insight into the social changes of the time and offers some encouragement to academic women today to continue to persist in their own struggles for full inclusion in academic life. We link the countries of Canada and Spain both then and now; we consider today's academic worlds in our countries offering both quantitative and qualitative, of what women continue to face.

Why Ritchie and Goyri? We see them as pioneers of the academic life in the Canadian and Spanish contexts with whom women a century later continue to share similar disadvantages. Ritchie and Goyri present some commonalities in their academic trajectories on two continents. They both were among the first women to obtain bachelor's degrees and doctorates. Both made significant contributions to academe early in the $20^{\text {th }}$ century encouraging the full inclusion of women in academic life. Goyri's legacy to Hispanic Philology and Ritchie's philosophical reflections and efforts to create the Maritime provinces a central point in Canadian culture are undeniable. Finally, they were both foundational in establishing a path for the many academic women who followed. 


\section{The contributions of Eliza Ritchie (1856-1933)}

Eliza Ritchie (born in Halifax in 1856) was the third daughter of a well-known lawyer, legislator and judge, John W. Ritchie, and his wife, Amelia R. Almon. The devoted parents provided their four children -three girls and one boy- with an enviable education and, after their deaths in 1890, left them more than enough resources to live the rest of their lives comfortably (Fingard, 2013). All four siblings shared interests in the arts, education and social causes, and they actively supported the broadening of women's roles in society.

Eliza Ritchie was only eleven years old when the Dominion of Canada was formed. Thus, she witnessed what has been called the "Great Transformation" (1891-1929), that is, the dramatic changes that occurred in her country in the decades following confederation: the population doubled, and the economy grew abruptly as the country's natural resources were brought into production (University of Toronto, 1990: Vol. III, 1). In 1891 , Canada's workforce was composed predominantly of males (88\%), with only $12 \%$ of the paid workforce comprising women (Canadian Human Rights Commission, n.d.: 1,2). As in all Western economies at the time, the contributions of women in the labour market and in their contribution to Gross Domestic Product was minimal. Most wage-earning women were in "feminine work": domestic service; low-paying factory jobs; teaching; or nursing.

Women's presence in higher education in the late-19th century was also very low and it had only become possible in the mid- $19^{\text {th }}$ century when public high schools opened their doors to female students (Strong-Boag, 1976: 11). However, by the early $20^{\text {th }}$ century, and especially after W.W.I, university attendance by both men and women grew significantly (University of Toronto, 1990: Vol. III), and universities began to play a major cultural, scientific and social role in Canadian life. In 1901, 11\% of full-time university undergraduates were women (Statistics Canada, 2018).

Eliza Ritchie was admitted to Dalhousie University in 1882, the year after women were first allowed to enter the institution (Dalhousie University, n.d., 1). She received her Bachelor's Degree of Letters from Dalhousie in 1887. Dalhousie had offered coeducation in arts and science since 1881, which was different from other Canadian universities (e.g., Mount Allison and McGill) that had established women's colleges (Fingard, 1984: 688). Despite this commingling of male and female students, at least one study has highlighted the university's "predominantly male ambience" and the discrimination against women staff at all levels at least until 1950 (ibidem: 688).

Ritchie maintained a relationship with Dalhousie University throughout her life. Although she never held a professional rank there, she donated her services to Fine Arts and was also an occasional student advisor. Between 1912 and 1913, she was the first warden (unpaid) of the Dalhousie women's residence, "Forrest Hall" (Fingard, 2010: 15). Ritchie called this residence a place "to provide a suitable home for earnest and intelligent young women who are working for the great ends of knowledge and power" (Ritchie, 1911: 145). Ritchie was also the first woman to serve as a member of the Dalhousie Board of Governors (1919-25), representing the Alumnae Association. In this role, she volunteered on behalf of Dalhousie women. Ritchie was also the first to receive an honorary degree from her alma mater. Since 1985, her contribution to the university has been recognized in the form of a scholarship named in her honour. She is remembered today on Dalhousie's website as "one of 'Dal's' most influential alumna".

Ritchie actually received her doctorate from Cornell University in Ithaca, New York in 1889, thus becoming among the first Canadian women to secure a Ph.D. (Fingard, 2013). Her dissertation explored the "nature of the personality," and it became her first - of many-publications. That same year, Ritchie accepted an academic position at Vassar College, New York. She then worked another ten years at Wellesley College in Massachusetts where she eventually secured the rank of associate professor.

After she left Wellesley, Ritchie returned to Halifax. She never again engaged in paid employment. She dedicated herself to a life of "studious leisure" at the same time that she practised community activism. One of her associations at this time was with the Victoria School of Art and Design in Halifax, where she started volunteering in 1905. She also maintained a close relationship with the Nova Scotia Museum of Fine Arts. She was a charter member of the Art Gallery from 1908 and, in the late 1920s, she was vice president of the art school's governing committee. She also supported the institution by buying pieces of art for its collection. In 1906, she became head of the Provincial Exhibition's Art Department. There, she selected paintings, sculptures and commercial art, among other artistic artifacts. Her devotion to art was impressive, and she passionately defended the importance of art education (íbidem, 2013).

Ritchie's list of publications reflects her multidisciplinary interests: philosophy, literature (especially poetry), art, and the defence of women's rights. One of her main interests was $17^{\text {th }}$-century philosophy, and particularly the figure of Baruch Spinoza (1632-1677). These interests were reflected in publications in The International Journal of Ethics and the Philosophical Review. In the former, she also published her reflections on philosophical questions of human existence. In the latter, she focused her interest on religion, determinism and Spinoza. In addition, she was a member of the American Philosophical Association. She wrote book reviews on philosophical texts written in many languages, including Italian, German and French (all of which she spoke fluently). Ritchie also published in the Dalhousie Review, from its inaugural issue in 1921 to 1932 , 
the year before she died. In several of these articles, she discussed Goethe, Erasmus, contemporary poets and Spinoza.

Her literary contributions were also significant. She edited a poetry anthology in 1931 entitled Songs of the Maritimes: An Anthology of the Poetry of the Maritime Provinces of Canada. In the foreword, she defends the character and individuality of the region known as "the home of the happy," claiming it as the cradle of Canadian literature and highlighting, in the selection of 125 poems, the region's beauty and spirit. Ritchie also promoted the creation of a library at Halifax's Local Council of Women. She continually advocated for greater support for libraries in educational institutions and made regular donations to Dalhousie's library. A second edition of poetry was published posthumously, this time of Ritchie's own poems. Entitled In the Gloaming (1935), the reader can recognize in the 37 poems therein Ritchie's love for philosophy, literature and art. As a pioneer of lifelong learning, she often traveled overseas, especially to Italy and England, and these adventures are also remembered in her poems.

Especially during the First World War years, Ritchie actively worked for the reform of municipal politics. Her two main concerns were women's exclusion from school boards and the rules that disqualified married women from participating in civic elections. She reported in a local newspaper in 1917, "It is not for any little group of 'intellectuals' in Halifax and a few other towns that we desire political freedom, we want the great mass of our people, men and women both, [to] be sensible of, and to exercise their responsibility for, the good government of the country". Ritchie's advocacy for women rights was in fact a part of all facets of her life, and much of her writing reflects her thoughts about the role of women in society. She believed herself to be part of a "New women" culture - a culture of individuals trying to think, speak and act for themselves-. In her talks and seminars, she insisted that the opportunities for women must equal those for men. Ritchie's activism centred on her prominent role in the Local Council of Women in Halifax as President of the Nova Scotia Equal Suffrage League (Fingard, 2010: 4). The Local Council of Women in Halifax was formed in 1894 and was dedicated to improving the lives of the region's women and children. Ritchie was one of the founding members and its most famous Council member. She also belonged to a group called the "Nova Scotia Five" with four other prominent suffragists. They laboured in the Women's Suffrage Movement for many years before finally, on April 26, 1918, The Nova Scotia Franchise Act gave women the right to vote in Nova Scotia's provincial elections. It was the first province to do so in Atlantic Canada.

\section{The contributions of María Goyri (1873-1954)}

In the late $19^{\text {th }}$ century, Spain -unlike Canada- was getting smaller. It had a history of over four centuries, during which time its Catholic monarchy had grown the nation into an empire- but this power began to crumble after the country lost the last of its colonies in 1898. María Goyri was born in Spain during the "First Republic" (1873-1874) and at the beginning of the Bourbon Restoration. Her mother, Amalia Goyri, was a woman of strong character and clear ideas. Amalia raised her daughter alone (Goyri's father is unknown), providing her a significant intellectual training. It was her mother who taught her grammar, at home, and it was there where the young woman found her true vocation; however, Goyri was interested in all subjects. The first years of her life were spent in the small seaside town of Algorta, Northern Spain, and she later moved to the capital, Madrid. Goyri cultivated a taste for theatre, sports, drawing and the French language. Eventually, she also learned to read in German, Italian, Latin and English. From a young age, she shared learning and hobbies with many boys, which facilitated her dealing with them when later at university -a point she herself acknowledged (Ontañón, 2013: 9)-.

As a young woman, she met the well-known scholar Ramón Menéndez Pidal (1869-1968). They became tightly linked from their very first meeting, becoming lovers and life-long intellectual partners. Menéndez Pidal was a key figure in the development of philology and Spanish history (Alonso, 1969: 99). He prepared his doctoral thesis on the writer and noble of the $14^{\text {th }}$ century, D. Juan Manuel, while she worked on a textual criticism of the most important work of the same author entitled, Count Lucanor. Menéndez Pidal and Goyri were married in 1900 and had three children. All of them became also engaged in research, publications and teaching throughout their lives. The couple worked together, from youth to old age, on the collection, organization and study of the "Spanish Romancer" considered one of the most celebrated creations of Spanish literature. Along with most of her colleagues and friends, they were part of the "Free Institution of Education", founded in 1876 by a group of professors that created a unique pedagogical project in Spain. The institution considered the progress of Spain as possible only through education and modern pedagogical principles. In fact, every academic center in which Goyri worked as professor was inspired by the principles of the Institution. Following those principles, a "master lesson" ceased to monopolize teaching; there was a clear abandonment to the notion of top-down instruction. The students in those academic institutions taught in a coeducational environment- were responsible of their own learning. Moral education, physical education and aesthetic training were pillars in the process, as was critical thinking, logic, and rhetoric (Herrero, 2015: 49). 
The first decades of the $20^{\text {th }}$ century, when Goyri was developing her academic career, were not stable times socially, politically or economically. The most important writers in Goyri's time were widely known as the "98 Generation." They all expressed their dissatisfaction with "the problem of Spain" and advanced necessary and profound reform in all spheres, including education (Laín, 2003: 432). During this time, there was a flowering of Spanish literature that would see three successive generations of prose poets and philosophers (Mainer, 1987: 20). After many years of Goyri's work and coinciding with the beginning of the Spanish Civil War (1936-1939), and especially during "Francoism" (1939-1975), many of Goyri's causes and concerns were destroyed. For example, the pedagogy of the "Free Institution of Education", and those institutions where Goyri worked and where that pedagogy was applied, were persecuted and eliminated during Franco time. Fortunately, she had accomplished and published a great deal by then.

Goyri's dedication to feminism emerged early in her life. In 1892 , coinciding with the $400^{\text {th }}$ anniversary of Columbus's "discovery of America", Goyri was a young woman already attending university. She assisted the Hispanic-Portuguese-American Pedagogical Congress, held in Madrid, by serving as a member of a congressional panel. The Congress gathered key intellectuals personages of the time, most of whom came from the academic world. Being a woman, it was expected that she would be a silent listener. Contrary to the facilitators' expectations, she passionately defended the rights of women to study in universities and to occupy posts reserved for men. Goyri saw women's inclusion in society as inevitable; she said "against progress cannot be fought" (Goyri in Moreno and Martínez, 2013: Vol. III, 348).

Goyri obtained many degrees - and excelled in all of her academic work. Even before entering university, Goyri obtained the title of Professor of Commerce from the Association for the Teaching of Woman. She also held the title of "teacher" from the "Normal Central School," and received a baccalaureate degree from the institute, Cardinal Cisneros. She then began her university "tour." During her first year, a male escort accompanied Goyri everywhere, including to professors' offices and to each class. Physically set apart from the rest of the students - all of whom were male - Goyri attended the lesson from a chair positioned near the professor. This arrangement fell into disuse during the years she was a doctoral student. Goyri obtained a B.A. in Philosophy and Letters from the Universidad Central (Madrid) in 1895, and completed her doctoral studies at the same university in the next academic year. She was the only female in her doctoral program, surrounded by 26 companions. Her doctoral dissertation entitled, The deceased pleaded: A comparative literature study, was published years later, in 1909.

Goyri was committed to addressing the social challenges of her time and she confronted these deficits in more than just her academic work. Throughout her life, she defended the notion that the development of society would only possible with the incorporation of all people. For example, for ten years between 1910 and 1920 , she actively collaborated on a center dedicated to the protection of delinquent children called the "Protectorate of Delinquent Children" and designed the training and participated in the management of the centre. She also collaborated with the "School of Crafts for homeless children" (Ontañón, 2017: 155).

Goyri did important pedagogical and teaching work as an academic. After achieving her doctorate, she taught literature and prepared other teachers for work in schools. She lectured at a coeducational pedagogical school founded in 1918 Institute-School under the auspices of the government. There she also designed a Spanish teaching syllabus and trained other teachers, in addition to working extensively in administration. Along with her husband, she also created the Literary Library of the Student, a curriculum that included a careful selection of adapted texts for new teachers to use. Goyri also was a professor of literature on the Residence of Ladies led by her friend and colleague, the educational pioneer María de Maeztu (1881-1948). The Residence was created in 1915 and endured until the beginning of the Spanish Civil War in 1936. Facilitating attendance at university in Madrid, it provided young women from all over Spain with a place to live and learn (Pérez-Villanueva, 2011). Goyri also taught at the neighboring International Institute, where she was Chair of the Scholarship Committee. This committee made it possible, for the first time in Spain, for female Spanish students to travel and study at American universities. Her last academic post was brief on account of failing health, as professor of literature at the Study-School, which was founded and directed by her daughter. Still in existence today, the Study-School (an elementary and secondary school) was built on innovative pedagogical ideals of the Free Institution of Education in the new and repressive Franco regime.

Nearly 40 publications, plus many other unpublished works, make up Goyri's bibliography. Her first publications showed her clear commitment to feminism: What the women think about their education (1893); Female chronicles (1898); and The next feminist congress (1899). She also published on material that was not directly related to her feminist work. For example, Goyri was a knowledgeable philologist, on which she published a variety of articles. Her publications also include work on Count Lucanor and the "Spanish Romancer", as well as on one of the most important poets and playwrights of the "Spanish Golden Age" and Lope de Vega (1562-1635). Goyri was also an expert on medieval literature, as was her husband, and this knowledge resulted in invitations in 1909 to various North American universities, including Johns Hopkins in Baltimore and Cornell - the last one being, coincidentally, where Ritchie obtained her Ph.D. some years earlier. He delivered lectures explaining "Spanish romancer" with a new critical approach and, although Goyri 
did not lecture then, she is considered a necessary collaborator in the content of the conferences delivered (Ontañon, 2017: 66).

The last years of her life were committed mainly to research in her home in Madrid. This was the very home where Goyri and her husband had worked for decades, hand in hand, as well as where they had hosted the era's intellectuals. Their home is now home to the "Ramón Menéndez Pidal Foundation"; it houses several archives including documentation about history of feminism, philology, literature, history of pedagogy, biographies and history of Spain.

For a complete list of Ritchie's and Goyri's bibliography, contact the authors.

\section{Ritchie and Goyri comparative analysis}

In the second half of the XIXth century, before Ritchie and Goyri were born, the "woman question" had become one of the most important topics of the day in Western societies. New job opportunities, marriage laws, female emigration and education were only some of the issues debated at the time. Women themselves, and particularly middle-class women, were increasingly concerned with what their roles both were and should be (Vicinus, 1980: 10). In many ways, the $19^{\text {th }}$ century acted as a hinge in the long history of women. Perhaps the most striking evidence of change among women was the emergence of women attending colleges. These women were predominantly white and from economically comfortable circumstances, though they ranged in age and marital status (Evans, 1989: 147). Ritchie and Goyri were among them. They were both raised in families that valued education - and indeed, family support is still considered one of the most crucial factors of women's advancement in academic institutions (Miller, 1985: 63).

The access of women to post-secondary education came mainly in the latter half of the $19^{\text {th }}$ century, though it began as early as 1833 in the United States. The same access was opened in the United Kingdom and Netherlands in 1871, and in Norway in 1882 (Stiver, 1990: 18). Canada and Spain opened up colleges and universities to women in 1859 and 1872 respectively (Bercuson, 1981, Flecha, 2006: 466). Some institutions were designed exclusively for women (e.g., in the US and UK), while others were coeducational (Montero, 2009: 45). However, women's presence in the universities was not followed by a proportional presence in the labour market, and this was particularly true in academic fields (Rodriguez, 2010: 216). In the States, for example, in 1921, "women held .001 percent of the professorships at male colleges and 4 percent of the professorships at coeducational institutions" -and these were almost always in the lower positions and at less prestigious institutions (Harris, 1978: 115-116)-. There were almost no women professors in Canada's universities during the 1920s, and in Spain women did not begin to be hired until 1932, at which time the nation employed 13 female professors (Rodríguez, 2010: 216).

Ritchie and Goyri were thus pioneers as female academics in faculty positions. With multidisciplinary interests mainly in the humanities, both promoted the development of culture, advocating the provision of libraries in public schools and enriching them. They both had the unique opportunity of traveling abroad and living in foreign academic systems. Both worked for years in residences for university women, encouraging these other women and broadening their knowledge. In their academic positions, they shared ideas about the role of women in society, fought for equality inside their own academic instructions, and followed an exceptional professional academic trajectory in a man's world. Consequently, they were derided as "bluestockings" and "feminists"-bachilleras in Spanish.

Ritchie and Goyri were both scholars, educators, authors, aesthetes and feminists. Ritchie is clearly recognized as a suffragist, especially in her work at the Local Council of Women in Halifax. Although we haven't found same specific commitment to women's suffrage in Goryri's life, her devotion to achieving women's equality is clear. Referring to the Spanish experience, scholars Mary Nash and Gloria Espigado have emphasized that the movement for the claim of rights and improvements for Spanish women is not comparable with the Anglo-Saxon model. In Spain a more social feminism than political occurred "and not as it happened in the Anglo-Saxon world, through an egalitarian-based suffrage model" (Perez, 2013: 276).

Ritchie died single, as did nearly half of all college-educated women in the late $19^{\text {th }}$ century (Evans, 1989: 147). Goyri, exceptionally, was married to an outstanding academic partner and had three children with him, but she was never treated as his equal in the public sphere.

\section{Women in the academia today: Canada and Spain}

We wonder how Ritchie and Goyri might view the university today. From when women were first admitted to university until now, the position of women in academia has changed dramatically. Today, women feature heavily in academic institutions in both Canada and Spain. In the 2015-16 academic year, Canada's 121 universities (92 public, 28 private non-profit, 1 private for-profit) hosted 1.3 million students, with the majority being women (56.7\%) (Statistics Canada, 2017b). In Spain in the 2014-15 academic year, its 82 universities 
(50 public, 32 private), taught 1.3 million students, also mainly women (54.3\%) (Ministerio de Educación, 2016: 10). In both countries, approximately $50 \%$ of the universities' doctoral students are women.

All that said, academia is a different scenario in terms of gender distribution. There are approximately 45,660 professors in Canadian universities at various levels (i.e., full, associate and assistant). Spain has more than twice this many, with 115,000 academics and researchers in public and private institutions. The proportion of women in academia are the same in both countries, and indeed is the average in all OECD countries (OECD, 2017a: 395): women represent 40\% of the faculty. Furthermore, statistics in both countries consistently show that the higher the rank in academia, the lower the percentage of women. Men comprise the majority of full professors in today's universities: $72 \%$ in Canada and $80 \%$ in Spain. This is a situation that differs enormously from primary and secondary schooling where the teachers are mainly women: $72 \%$ in Canada and $78 \%$ in Spain. An average of $83 \%$ of non-post-secondary teachers in all OECD countries are women.

It has been interesting to consider how resistant the West has been in regards to women in positions of authority. Females are badly represented in top academic staff positions. For example, only $20 \%$ of university presidents in Canada are females, and only $25 \%$ are at the vice-level. After requesting statistical data in terms of gender of who runs universities to the official statistical institutions in both countries, we were informed that such statistics don't exist because the sample size would be too small. A manual recount on the web sites of Spanish institutions shows us clearly that being a female provost is rare (8\%). On average throughout the European Union (EU-28), only $15.5 \%$ of higher education institutions are headed by women (European Commission, 2013: 114).

Remuneration is an essential aspect of working conditions. As the report of Eurydice-European Commission reminds us (2017: 78), developing a full academic career implies having adequate and secure salaries in addition to the option of full-time employment. It is not only a personal goal but also a necessary condition for the development and prestige of universities. From an international perspective, it is also necessary to understand how being a professor is asymmetrically remunerated by various countries. Canadian professors (male and female) have a privileged situation in terms of salary in comparison with their European colleagues. A full professor in Spain can earn between 40,558 $€(\$ 61,946$ CAD) and 62,187 $€(\$ 95,148$ CAD) (UNED, 2017) (Universidad Complutense, 2015). In the case of an associate professor in Spain with a doctorate and some years of experience in teaching and researching, the salary is, on average, 35,000 $€(\$ 53,459 \mathrm{CAD})$. This is less than half of what an associate professor on average earns in Canada $(\$ 109,600 \mathrm{CAD}$, UCASS 2012). And, it is not only Spain that has such low salaries than Canada; all of Europe seems to pay much less to academic faculty. Remuneration is the biggest disparity when comparing the academic careers between countries (Eurydice, 2017: 82).

Despite the interest in the gender gap over the last several decades, only $1.15 \%$ of the articles in higher education journals have analyzed gender differences between faculty members between the years 2000 and 2013 (Gómez et al., 2015: 62). What we can learn from these journals includes the following: women are more likely to be employed at less elite institutions and in less prestigious disciplines; women are underrepresented in full-time positions, take longer to be promoted and are less paid when they are (August and Waltman, 2004: 177); women devote more time to lecturing and advising than researching, and they rarely teach in fields for which they are trained (Sax et al. 2002: 423). Moreover, a European Commission report claims that the strong vertical segregation of women's academic careers regarding women in high-power positions can "act as an obstacle for the access of young women into the PhD level and the first stages of the academic career" $(2013,114)$. In addition, one of the most persistent differences in research productivity is found in American and European studies between academic men and women (Reza, 2002: 152). Lower productivity in women is often explained by reference to familial status and responsibilities, but can also be explained by "significant "structural and systemic discriminatory practices within the profession" (Aiston et al., 2015: 217).

National accreditation systems of professors, established in Spain, but also existing in other European countries such as Italy or Portugal are accused of being discriminatory in the segregation by sex and of increasing inequalities in the access and promotion of female professors (Eurydice, 2017: 40); being an accredited professor goes through a tedious process that generates a disproportionate abandonment in women's academic careers (Solà and Rovetto, 2008: 290). Success in accreditation is demonstrated by a solid research trajectory with publications in prestigious journals. However, it is not necessarily clear that being a good professor is the same thing as being a good researcher (Carabaña, 2003: 14).

\section{Some Conclusions}

In the lives of both Eliza Ritchie and María Goyri, we see a profound commitment to academic life. Both were prolific and dedicated to establishing a significant legacy. Both invested in community ideas and found ways to support women as intellectuals. In their respective countries, they paved the way for women who came afterwards to claim their own ideas and to believe in their significance to others who would follow. Both founded institutions that outlasted them. They used their lives to promote feminist causes and found a way to 
be thinkers and scholars as women in their particular time and place. They helped envision a place for women in academia and left an incredible body of academic work as evidence of the academic contributions women have made.

It is important to look at herstory and consider ideological and practical commitments in academic life for a number of reasons, two of which we feel are pertinent here. First, it is important to comprehend the "history of women" beyond the specificity of national histories and cultural and political gaps. Second, it is important to understand how women such as Ritchie and Goyri carved out a path and how their life experiences can encourage women in academia today in regards to the inequalities that persist.

Female professors in Ritchie's Dalhousie University as well as at Universidad Central in the time of Goyri-owe them a lot. Indeed, we all have a lot to thank them for. Both made significant cultural changes to their respective countries, and they confronted the international challenge regarding the role of women's place in academia. In many ways, they serve as models for today's female academics in the way that they dedicated time and energy to supporting those who followed them: building on their examples, we are inspired to do the same. We aim to look for and establish entities that will outlive us, and we strive to pour our energy into bettering the lives of women in particular. Both authors have faced barriers on our respective academic journeys. The obstacles faced by Ritchie and Goyri give us a shared camaraderie with them and with each other. As women, we share the limitations of a modern world when it comes to how we manage our academic careers. There are systemic injustices that we must both live with and challenge-for us and for those who follow in our footsteps. We must not be stifled by despair. After all, the system is changing because our predecessors fought for themselves and for us. Thus, we feel compelled to continue the legacy of feminism in making the path easier for the next generation of women.

When we consider the increased options for women in academia since the times of Ritchie and Goyri, we can see how significant their trailblazing was. Women in Western cultures now fully have the right to an education (recognized in Spain by its Constitution of 1978 and in Canada as contained in the provincial education acts). By taking an historical perspective, we have been able to ponder the role of women in academia and to set up an understanding of how heroic our female predecessors were in charting this new path. We have tried in our research here to better understand how the early years of being a female academic compares internationally and to consider how the past 150 years have continued to present obstacles to women's academic achievements. The gender imbalances that remain suggests more progress is still needed to make room for women at the top.

In light of the evident gender gap, we have been disappointed about the paucity of discussion on the topic in our own workplaces, as well as about the lack of energy put towards the betterment of and prosperity for all women in academic today. The gender gap in academia reveals inequality in pay, research funding, senior positions and the feminization of precarious and low-paid positions. As we established above, there is no doubt about the predominance of women attending university, and yet $60 \%$ of faculty in both countries are men. Very few women have a role in the direction, government and management of universities. This can -and shouldchange.

The lack of gender parity is a global issue. Clearly, there is a necessity to understand the academic world and the role of women in it beyond the borders of Canada and Spain. There need to be more studies on the longterm perspectives; and more literature on academic institutions as a macro problem and at the micro-level too. In addition, we need comparable statistics between countries of the salaries of professions and in university leadership.

In relation to the academic worlds of Ritchie and Goyri, there is more room and acceptance for women today. But the current realities are still disheartening. Where are there so few women in positions of leadership? In high-level research in their areas of expertise? Why are there any discrepancies in salary? Is it that women have been invited into the academic "house," so to speak, but have not been given the "room" to flourish? We are convicted that examining the lives of earlier feminist academics such as Ritchie and Goyri can provide a needed boost to women in academia today.

Female scholars of the $21^{\text {st }}$ century must draw on our own life experiences in our intellectual work and continually examine our gendered positions. The gender gap in academia takes different forms in each region and country, including the institutional and disciplinary context, but it raises a set of shared questions that are urgent. We must collectively and critically examine them. International collaborations such as ours play an important role in achieving this kind of critical examination of gender and gender inequality. Through our collaborative work and comparative analysis, we honour Woolf's challenge to explore the shared experiences of women and consider the conditions in which we live and work. Examining Ritchie and Goyri together help advance stories where "some room for us" can and should exist.

It would be better to draw the curtains; to shut out distractions; to light the lamp; to narrow the enquiry and to ask the historian, who records not opinions but fact, to describe under what conditions women lived. Virginia Woolf, A room of one's own. (1929) 


\section{Bibliography}

Aiston, Sarah Jane, JUNG, Jisun. (2015): "Women Academics and Research Productivity: An International Comparison." Gender And Education 27, no. 3: pp. 205-220. ERIC, EBSCOhost.

Alonso, Dámaso (1969): Menéndez Pidal y la generación del 98. Complete Works. Vol. IV. Madrid: Gredos.

Baker, Maureen (2012): Academic Careers and the Gender Gap. Vancouver: UBC Press.

Bercuson, David. Buckner, Phillip. (1981): Eastern and Western Perspectives, Papers from the joint Atlantic Canada/ Western Canadian Studies Conference. Toronto: University of Toronto.

Canadian Human Rights Commission (CHRC). n.d.1 "Population and People January 1, 1900.” www.chrc-ccdp.gc.ca/ historicalperspective/en/getBriefed/1900/population.asp.

Canadian Human Rights Commission (CHRC). n.d.2 “Women's Rights January 1, 1900.” www.chrc-ccdp.gc.ca/ historical-perspective/en/getBriefed/1900/women-rights.asp.

Carabaña, Julio (2003): "La carrera del profesor universitario: cada vez más larga, más pobre y más precaria." Ciclo de conferencias. Universidad de Valencia.

Curtis, John W (2011): "Persistent Inequity: Gender and Academic Employment". Prepared for "New Voices in Pay Equity" an event for equal pay day, April 11, 2011 Association of American University Professors.

Duby, Georges. Perrot, Michelle (ed.) (1994): History of Women in the West. Vol. 4 \& 5. Cambridge, Mass.: Harvard University Press.

Dalhousie University, n.d.1 "Timeline: A snapshot of our 200-year academic history" https://www.dal.ca/about-dal/ history-tradition/timeline.html.

Evans, Sara M (1989): Born for Liberty. A History of Women in America. New York. The Free Press.

European Commission (2013): She Figures 2012: Gender in research and innovation. Brussels: European Commission.

Eurydice, European Commission (2017): "Modernisation of higher education in Europe: Academic staff - 2017" https:// publications.europa.eu/es/publication-detail/-/publication/7f61ba68-5499-11e7-a5ca-01aa75ed71a1/language-en/ format-PDF.

Fingard, Judith (1984): "Gender and inequality at Dalhousie: Faculty women before 1950" Dalhousie Review, Vol. 64 Issue 4, pp. 687-703.

Fingard, Judith. (2010): "The Ritchie Sisters and Social Improvement in Early 20th Century Halifax" Journal of the Royal Nova Scotia Historical Society, $\mathrm{n}^{\circ} 13$. https://ezproxy.student.twu.ca/login?url=https://search.proquest.com/ docview/881833894? accountid=14411

Fingard, Judith (2013): "Eliza Ritchie." Dictionary of Canadian Biography, Vol. 16 (1931-1940), University of Toronto/ Université Laval, 2003-, http://www.biographi.ca/en/bio/ritchie_eliza_16E.html

Flecha, Consuelo (2006): "Mujeres en Institutos y Universidades" (455-483). Historia de las Mujeres en España y América Latina. Del Siglo XIX a los Umbrales del XX (Isabel Morant) Madrid: Cátedra.

Gómes, Mamen, Larrán, Manuel and ANDRADES, Francisco (2016): "Gender differences between faculty members in higher education: A literature review of selected higher education journals." Educational Research Review. https:// doi.org/10.1016/j.edurev.2016.03.001

Harris, Robin (1976): A History of Higher Education in Canada (1663-1960). Toronto: University of Toronto Press.

Harris, Barbara (1978): Beyond her sphere: Women and the professions in American history. Westport, Conn. Greenwood Press.

Herrero, Sara (2015) “'Docentes y Referentes: María Goyri (1873-1954)”. Revista de Occidente nº 413. Madrid: Fundación José Ortega y Gasset-Gregorio Marañón.

Historical Statistics Of Canada (2014): Population and Migration. Table A1."Estimated population of Canada, 1867 to 1977" http://www.statcan.gc.ca/pub/11-516-x/3000140-eng.htm

Laín, Pedro (2003): “La generación del 98 y el problema de España.” Arbor No 174. https://doi.org/10.3989/arbor.2003. i687-688.652.

Lapierre, Jo (1990): “The academic life of Canadian coeds 1880-1900." Historical Studies in Education. http:// historicalstudiesineducation.ca/index.php/edu_hse-rhe/article/view/1315/1455

Lee, Young-joo, Doyeon, Won (2014): "Trailblazing women in academia: Representation of women in senior faculty and the gender gap in junior faculty's salaries in higher educational institutions." The Social Science Journal. Vol 51. https://doi.org/10.1016/j.soscij.2014.05.002

Mainer, José Carlos (1987) : La Edad de Plata (1902-1939):ensayo de interpretación de un proceso cultural. Madrid: Cátedra.

Miller, Barbara (1985): In the company of Educated Women. Yale University Press. New York.

Ministerio de Educación, Cultura y Deporte. 2016. "Datos y cifras del Sistema universitario Español. 2015/2016." Madrid: Secretaría General Técnica. https:/www.mecd.gob.es/dms/mecd/servicios-al-ciudadano-mecd/estadisticas/ educacion/universitaria/datos-cifras/datos-y-cifras-SUE-2015-16-web-.pdf

Montero, Mercedes (2009): La conquista del espacio público: mujeres españolas en la universidad (1910-1936). Madrid. Minerva.

Moreno, Javier, Martínez, Fernando (editors) (2013) : La Institución Libre de Enseñanza y Francisco Giner de los Ríos: Nuevas Perspectivas. Volumen I, II, III.Madrid: Fundación Francisco Giner de los Ríos y Acción Cultural Española. 
OECD. (2017a): Education at a Glance 2017: OECD Indicators. Paris: OECD Publishing. http://dx.doi.org/10.1787/ eag-2017-en

OECD. (2017b): “The Pursuit of Gender Equality: An Uphill Battle." Paris:OECD. http://dx.doi. org/10.1787/9789264281318-en

Ontañón, Elvira (2007): “El Instituto-Escuela, una Experiencia Educativa Ejemplar. Circunstancia, n 14 http://www. ortegaygasset.edu/publicaciones/circunstancia/ano-v---n--14---septiembre-2007/ensayos/el-instituto-escuela--unaexperiencia-educativa-ejemplar

Ontañón, Elvira (2013): “María Goyri (1873-1954)”, Estudio Boletín de actividades. 19, junio 2013, pp. 8-13 http://www. fundacionramonmenendezpidal.org/images/pdfs/Elvira\%20Ontan.pdf

Ontañón, Elvira (2017): “María Goyri. Su Mundo y su Entorno 1873-1954.” PhD diss., Universidad Complutense. Madrid

Pérez-Villanueva, Isabel (2011): La residencia de estudiantes. Grupo Universitario y Residencia de Señoritas (19101936). Madrid: Consejo Superior de Investigaciones Científicas

Reza, M. (2002): "Gender differences in publication among university professors in Canada." Canadian Review Of Sociology And Anthropology-Revue Canadienne De Sociologie Et D Anthropologie 39, no. 2: 151-179. EBSCOhost

Ritchie, Eliza. (1901): “Women and the Intellectual Virtues.” International Journal of Ethics 12, No. 1. pp. 69-80 http:// www.jstor.org/stable/2376221

Rodríguez, Carolina. (2010) “Experiencias universitarias en torno a 1910.” CEE Participación Educativa.

Rogers, Chrissie. (2017): "I'm complicit and I'm ambivalent and that's crazy: Care-less spaces for women in the academy." Women's Studies International Forum 61, pp. 115-122.

Sax, Linda, Serra, Linda, Arredondo Marisol, and Dicrisi, Frank. (2002): "Faculty Research Productivity: Exploring the Role of Gender and Family-Related Factors." Research in Higher Education no. 4: 423. JSTOR Journals, EBSCOhost.

Solà, Nuria, Rovetto, Florencia (2008): «La situación de las profesoras jóvenes en la Facultad de Ciencias de la Comunicación de la UAB.» Zer: Revista De Estudios De Comunicacion 13, no. 25. EBSCOhost.

Statistics Canada (2017a) Table 477-17 "Full time teaching staff at Canadian Universities, by rank an sex" http://www. statcan.gc.ca/tables-tableaux/sum-som/101/cst01/educ68a-eng.htm

Statistics Canada (2017b) Table 477-19 "Postsecondary enrolments by institution type, registration status, province and sex (2014-2015)." http://www.statcan.gc.ca/tables-tableaux/sum-som/101/cst01/educ71c-eng.htm

Statistics Canada (2017c): "Full-time teaching staff at Canadian universities, by rank and sex." Table 477-0019 http:// www.statcan.gc.ca/tables-tableaux/sum-som/101/cst01/educ68a-eng.htm

Statistics Canada (2018): Series W439-455 "Full-time university undergraduate enrolment, by field of specialization and sex, Canada, selected years, 1861 to 1975." Section W: Education. https://www.statcan.gc.ca/pub/11-516-x/ sectionw/4147445-eng.htm

Statistics Canada. University and College Academic Staff System (UCASS). 2012. Table 4. "Full-time teaching staff at Canadian degree granting institutions (universities and colleges)"

Stiver, Suzanne; O'Learly, Virginia (1990). Storming the tower: Women in the academic world. London: Kogan Page, 1990.

Strong-Boag, Veronica J (1976): The parliament of women: the National Council of Women of Canada, 1893-1929. Ottawa: National Museums of Canada. Alloway Library Catalogue, EBSCOhost.

UNED (2017) : “Portal de transparencia. Retribuciones.” http://portal.uned.es/portal/page?_pageid=93,49441476\&_ $\mathrm{dad}=$ portal\& $\mathrm{schema}=$ PORTAL

Universidad Complutense (2015): "Portal de Transparencia. Retribuciones PDI funcionario". https://www.ucm.es/ portaldetransparencia/retribuciones-pdi-funcionario-1

University Of Toronto (1990): "Historical Atlas of Canada: Addressing the Twentieth Century, 1891-1961.” Volume III. Edited by Cole Harris, Geoffrey J. Matthews. Toronto: University of Toronto Press.

Vicinus, Martha (1980): A widening sphere: changing roles of Victorian women. London: Methuen \& Co.

World Academic Forum (2016): The global gender gap. Geneva: World Economic Forum. 